\title{
3+1 İş Başında Eğitim Uygulaması Modelinin Kahramankazan Meslek Yüksekokulu Örneğinde Değerlendirilmesi
}

\author{
${ }^{1}$ Öğr. Gör. Sinan Can ALTUNTAȘ \\ ${ }^{2}$ Doç. Dr. Erkan YILDIZ \\ ${ }^{3}$ Prof. Dr. Feride İffet ŞAHIN
}

\section{ÖZET}

Bu çalışmada, Başkent Üniversitesi Kahramankazan Meslek Yüksekokulu tarafından 2020-2021 Akademik Yılı Bahar Döneminde gerçekleştirilen 3+1 İş Yeri Uygulamasından elde edilen sonuçlar tartışılmıştır. Pandemi koşulları nedeniyle uygulama 12 hafta süreyle icra edilmiştir. Uygulamaya katılma hakkı olan 227 öğrencinin \%68,7'si (N=156) 139 farklı firmada eğitimlerini tamamlamıştır. Öğrencilerden \%62,8'i (N=93) uygulama yaptıkları firmalardan iş teklifi almıştır. İş teklifi alan öğrencilerin \%32,4’ü $(\mathrm{N}=48)$ iș teklifini kabul etmiștir. Öğrenci algılarına göre uygulama; planlı ve düzenli çalışmanın öğrenildiği, ekip çalışmalarının nasıl gerçekleştirildiği ve okulda verilen teorik bilgilerin iş yaşantısındaki pratik karşılıklarının ne olduğunun kavranıldığı bir faaliyet olarak değerlendirilmiştir. Öğrenci kabul eden firma algılarına göre de öğrencilerin verimli çalışarak firmalara katkı sağladıkları tespit edilmiştir. Aynı zamanda iş yaşamına hazırlık açısından çok önemli bir faaliyet olduğu belirtilmiştir.

Anahtar Kelimeler: Mesleki Eğitim, Meslek Yüksekokulu, 3+1 İş Yeri Uygulaması Modeli

\section{Assessment Of 3+1 On-The-Job Training Application On The Case Of Kahramankazan Vocational School Of Higher Education}

\begin{abstract}
In this study, the outcome acquired from the 3+1 Workplace Application accomplished by Başkent University Kahramankazan Vocational School of Higher Education during the Spring Semester of the Academic Year 2020-2021 is discussed. The application has been executed for a period of 12 weeks due to the conditions imposed by the pandemic. $68.7 \%$ of 227 students $(\mathrm{N}=156)$ entitled to be included within the application have completed their training in 139 different enterprises. $62.8 \%(\mathrm{~N}=93)$ of the students have received job offer from the enterprises of application. $32.4 \%$ of the students receiving job offers $(\mathrm{N}=48)$ has accepted the job offers. The application based on the perceptions of the students has been assessed as an activity in where concepts such as planned and systematic studying is learned, how the team works are realized and the practical equivalents of the theoretical knowledge in the professional life are comprehended. Based on the perceptions of the enterprises admitting the students, it has been further identified that the students worked efficiently and thus, contributed to the enterprises. Moreover, it has been stated that the application is of utmost importance in terms of preparation for the professional life.
\end{abstract}

Keywords: Vocational Education and Training, Vocational School, 3+1 Workplace Application Model

\section{GíRiş}

Meslek yüksekokulları sektörün ihtiyaç duyduğu nitelikli meslek elemanlarını yetiştirmek üzere kurulmuş eğitim ve öğretim kurumlarıdır. Son yıllarda üniversite-sektör iş birliklerinin önemi her geçen gün artmaktadır. Bu kapsamda iş birliklerini ön plana çıkaracak projelere çok daha fazla yer verilmektedir. Konunun önemi doğrultusunda mesleki eğitimin önemi her geçen gün daha da

\footnotetext{
${ }^{1}$ Sorumlu yazar: Başkent Üniversitesi Kahramankazan Meslek Yüksekokulu, scaltuntas@baskent.edu.tr

${ }^{2}$ Başkent Üniversitesi Kahramankazan Meslek Yüksekokulu, eyildiz@baskent.edu.tr

${ }^{3}$ Başkent Üniversitesi Kahramankazan Meslek Yüksekokulu, drferidesahin@gmail.com
} 
belirginleşmektedir. Dolayısıyla meslek yüksekokulları da sektörün ihtiyaçlarına cevap verebilecek donanıma sahip öğrenciler yetiştirebilmek için modern eğitim ve öğretim yöntemlerine yoğunlaşmaktadır.

Bu doğrultuda meslek yüksekokullarındaki örnekler incelendiğinde $3+1$ ve $3+3$ modellerinin sınırlı sayıda üniversite tarafından uygulandığı gözlemlenmektedir. Belirtilen modeller içinde 3+1 uygulamasının çok daha fazla tercih edildiği tespit edilmiştir. Yüksek Öğretim Kurulu da konunun ülkemiz açısından önemine binaen, yaptığ toplantılarla üniversitelere $3+1$ modeline geçmelerini tavsiye etmektedir. $3+1$ modelinde ilk üç dönemi okulda tamamlayan öğrenciler gerekli kredi ortalamasını tutturmaları halinde dördüncü dönemde 14 hafta süreyle işyerlerinde, işyerlerinin kurallarına tabi olarak çalışmaktadır.

Bu çalışmada, Başkent Üniversitesi Kahramankazan Meslek Yüksekokulu tarafından 20202021 Akademik Y1lı Bahar Döneminde gerçekleştirilen 3+1 modeli uygulamasından elde edilen sonuçlar tartışılmıştır. Pandemi koşulları nedeniyle uygulama 12 hafta süreyle icra edilmiştir. Uygulamaya katılan öğrenciler ve öğrenci kabul eden firmalardan anket yöntemiyle elde edilen veriler değerlendirilmiştir.

\section{KAVRAMSAL ÇERÇEVE}

Günümüzde teknolojinin sağlamış olduğu iletişim imkânları ve sınırsız bilgiye erişim sayesinde dünyada her şeyin çok çabuk değişiklik gösterdiği gözlemlemekte ve bu değişikliklerden hemen haberdar olunabilmektedir. Meydana gelen değişiklikler ve yeni ihtiyaçların ortaya çıkması nedeniyle insanlar için kurgulanmış olan sistemler zaman içerisinde revizyona tabi olmaktadır. Bir ülkenin diğer ülkelerden daha iyi bir konuma gelebilmesi ve ülkenin rekabet avantajı elde edebilmesi için eğitim ve öğretim alanındaki yenilikler ve revizyonlar da bu kapsamda önem arz etmektedir.

Birçok yükseköğretim kurumunda teori tabanlı ve odaklı eğitim öğretim faaliyetleri büyük bir paya sahiptir. Fakat sadece teorik içeriğe sahip eğitim ve öğretim faaliyetleri ile istihdam sistemi istenilen başarı düzeyine ulaşamamaktadır. Yaşanılan bu durumun önüne geçebilmek ve yükseköğretim kurumlarının hem ulusal hem de uluslararası alandaki başarılarını arttırmak amacına istinaden teorik eğitim öğretim faaliyetlerine ek olarak uygulamalı eğitim öğretim faaliyetlerinin de tüm yükseköğretim kurumlarında uygulanması gereklilik arz etmektedir. Uygulamalı eğitim öğretim sisteminin yükseköğretim kurumlarında icra edilmesi üniversitede öğrenilen teorik bilgilerin pratik uygulamalar ile örtüştürülmesi adına önemli bir adım ve birçok açıdan kazanç sağlayan bir faaliyettir. Bu kapsamda bazı yükseköğretim kurumları uygulamalı eğitimlere daha fazla önem verirken bazıları ise halen sadece teorik eğitim öğretim ile öğrencilerini mezun etmektedir.

Uygulamalı eğitim öğretim modellerinin yükseköğretim kurumlarında icra edilmesi neticesinde eğitim öğretim sistemine dâhil olmuş olan öğrenciler teorik eğitimin yanında pratik uygulamalar ile elde edecekleri mesleki ve teknik bilgileri işletmelerde, kurum ve kuruluşlarda birebir, fiilen ve yüz yüze tanıma imkânına sahip olmaktadır. Dolayısı ile iş hayatı ve ilgili sektör hakkında daha öğrencilik yaşamlarında tecrübe elde edebilmektedirler.

Birçok uygulamalı eğitim öğretim modeli bulunmakla birlikte yükseköğretim kurumunun bulunduğu bölge yapısı ve özellikleri dikkate alınarak öğrenci, öğretim elemanı ve çevredeki kurum kuruluşların istek ve talepleri gözetilerek en uygun uygulamalı eğitim modelinin ilgili yönetmelikler çerçevesinde realize edilmesi büyük önem arz etmektedir.

Yükseköğretimde Uygulamalı Eğitimler Çerçeve Yönetmeliği 2021 yılının Haziran ayında resmi gazetede yayımlanarak yürürlüğe girmiştir. Yayımlanan bu çerçeve yönetmelik ile staj, mesleki eğitim ve uygulamalı eğitim faaliyetlerinin nasıl ve ne şekilde yapılacağı, izlenecek olan yollar, uygulamalar hakkında ilkeler ve kurallar tüm detayları ile açıklanmaktadır. 
Başkent Üniversitesi Kahramankazan Meslek Yüksekokulunda uygulamalı eğitime geçiş için gerekli olan hazırlık faaliyetlerine 2016-2017 akademik yılında başlanmış ve ilk kez fiili olarak 2018-2019 akademik yılında öğrenciler ilgili sektörlere ve işletmelere yönlendirilerek uygulamalı eğitime başlanmıştır. 2019-2020 akademik yılında dünyada ve Türkiye'de meydana gelen Covid-19 Pandemisi dolayısıyla uygulamalı eğitim ya da diğer bir adıyla $3+1$ olarak temalaşan İş Yeri Uygulaması faaliyeti uzaktan eğitim yöntemine uyarlanarak bu sürecin ödev, proje, araştırma, okuma-yazma-izleme gibi yöntemler ile tamamlanması sağlanmıştır. 2020-2021 akademik yılında da Covid-19 Pandemisinin devam etmesi gerekçesi ile öğrencilerin talepleri göz önüne alınarak iş yeri uygulaması dersi hem uzaktan hem de işletmelerde yüz yüze ve fiilen icra edilmiştir.

\section{METODOLOJI}

2020-2021 Akademik Yılında 3+1 İş Yeri Uygulaması eğitimine katılan öğrenciler ile öğrenci kabul eden firmalardan anket tekniği ile veriler toplanmıştır. Toplanan veriler SPSS Statistics 25 programı ile analiz edilmiştir.

Öğrencilere uygulanan ankette 37 adet soru yer almıştır. Anketin birinci bölümünde; yaş, cinsiyet ve öğrencinin kayıtlı olduğu programa yönelik 3; ikinci bölümde iş yerinin özelliklerini ve öğrencilere sağlanan hakları tespit edebilmek için 10 adet soru yöneltilmiştir. Üçüncü bölümde de uygulama öncesi faaliyetler için 2, uygulama esnası faaliyetler için 8 , uygulanan modelle ilgili 7 ve Pandemi koşullarına yönelik de 2 olmak üzere toplam 19 ifade sorulmuştur. Anketin dördüncü ve son bölümünde ise açık uçlu 5 adet soru yer almıştır. Açık uçlu sorularla; öğrenci ve iş yeri kaynaklı yaşanan sosyal problemler, Pandemi koşullarından kaynaklanan olumlu/olumsuz süreçler, iş yerinin değerlendirilmesi ve 3+1 modeli uygulamasına yönelik olumlu/olumsuz özellikler araştırılmıştır.

Firmalara uygulanan ankette 23 adet soru yer almıştır. Firma yetkilisinin kimlik ve iletişim bilgileri 3 soruyla anketin birinci bölümünde tespit edilmiştir. İkinci bölümde 7 soruyla; iş yerinin özellikleri, öğrencilere sağlanan haklar, beklentiler ve istihdam planları belirlenmiştir. Üçüncü bölümde uygulamaya yönelik firma algılarını ölçebilmek için 10 adet ifade sorulmuştur. Anketin dördüncü ve son bölümünde de Pandemi koşullarında yapılan uygulamaya yönelik değerlendirmeler, öğrenci kaynaklı sosyal problemler ile 3+1 modelinin olumlu/olumsuz yönleri 3 açık uçlu soru ile araştırılmıştır.

\section{BULGULAR VE TARTIŞMA}

İş başında eğitim uygulaması öncesinde Pandemi koşulları nedeniyle öğrencilerden onam formu alınmıştır. Onam formlarında öğrenciler, uygulamaya fiilen katılma ya da ödev, proje vb. etkinliklerle uygulamayı uzaktan yapmaya yönelik isteklerini beyan etmişlerdir. Onam formu sonuçları Tablo 1'de sunulmuştur.

Tablo $13+1$ Modeli Onam Formu Sonuçları

\begin{tabular}{|c|c|c|}
\hline $\begin{array}{c}\text { Uygulamaya Gitme Hakkı } \\
\text { Olan Öğrenci Sayısı }\end{array}$ & $\begin{array}{c}\text { Uygulamaya Fiilen Katılmak İsteyen } \\
\text { Öğrenci Sayısı }\end{array}$ & $\begin{array}{c}\text { Uygulamaya Katılmak } \\
\text { İstemeyen Öğrenci Sayısı }\end{array}$ \\
\hline 227 & 156 & 71 \\
\hline
\end{tabular}

Tablo 1'den görüleceği üzere öğrencilerin \%68,7'si $(\mathrm{N}=156)$ onam formlarına istinaden uygulamaya fiilen katılmışlar ve uygulamayı başarılı bir şekilde tamamlamışlardır. Öğrencilerin \%31,3'ü de $(\mathrm{N}=71)$ ödev, proje vb. etkinliklerle eğitimlerini uzaktan tamamlamışlardır. Uygulamaya katılan öğrencilerin programlara göre dağılımı Grafik 1'de gösterilmiştir. 


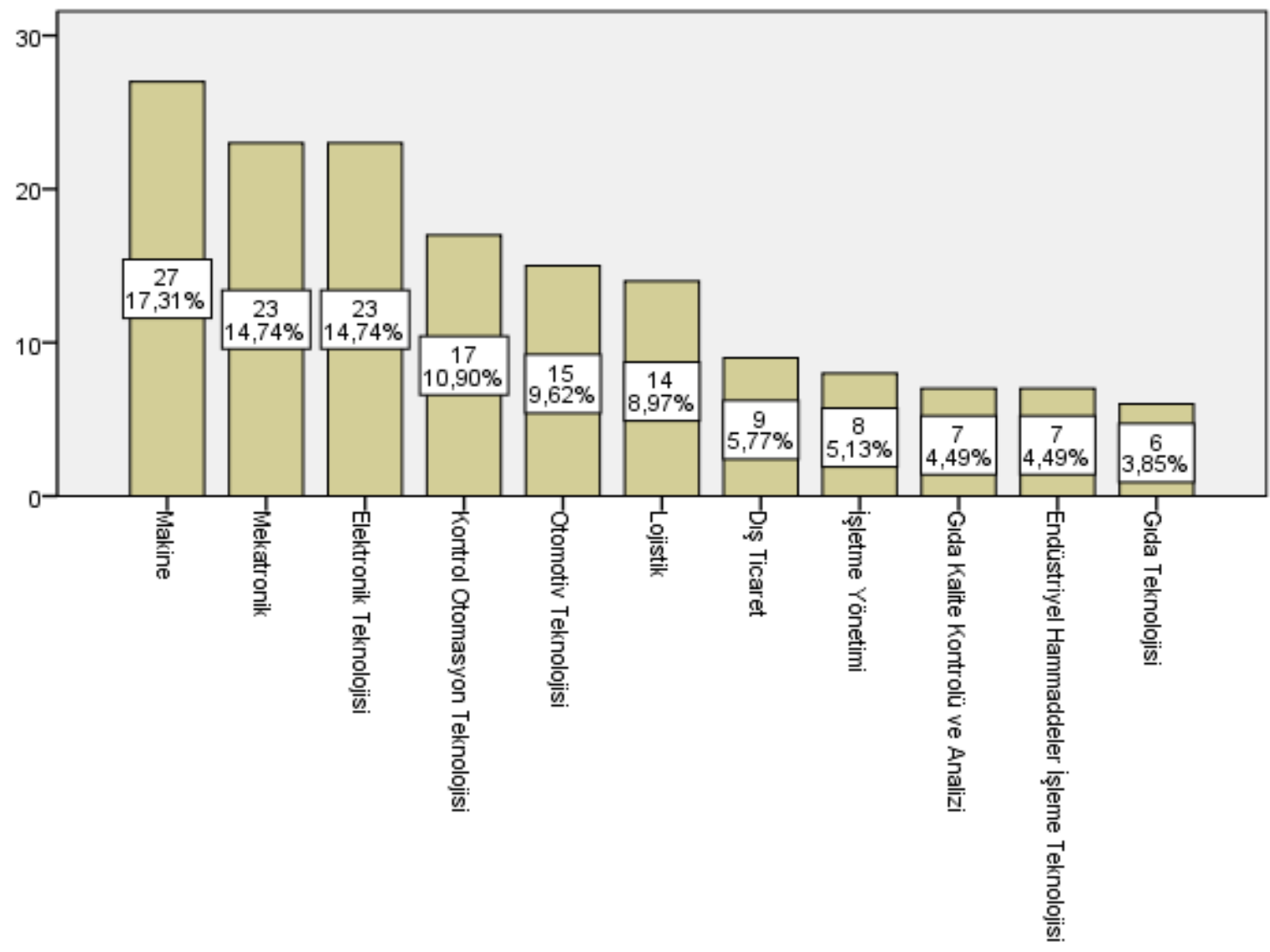

Grafik 1 Program Bazlı Öğrenci Sayıları

Uygulamaya katılan 156 öğrencinin 148 'inden anket verileri elde edilmiştir. Bu nedenle öğrencilerle ilgili sunulan bilgiler 148 öğrenci verilerine göre ifade edilmiştir. Ankete katılan öğrencilerin \%18,9'u kız (N=28), \%81,1'i erkek ( $\mathrm{N}=120)$ öğrencidir.

Uygulama 139 farklı iş yerinde gerçekleştirilmiştir. Bu firmalar içerisinde MAN, Karel, Anadolu Efes, Yiğit Akü, Sersim, Aras Kargo, UPS Kargo, Selçuk Ecza Deposu vb. çok büyük miktarlarda eleman istihdam eden iş yerleri mevcuttur. Öğrencilerin \%78,4'ü $(\mathrm{N}=116)$ uygulama yapmak istedikleri iş yerlerini kendileri önermiş, \%21,6'sına ( $=32)$ ise öğretim elemanları tarafindan yer bulunmuştur.

Öğrencilerin uygulamalarını yaptıkları iş yerlerinin faaliyet alanları Grafik 2'de çalıştıkları departmanlar da Grafik 3'te gösterilmiştir. 


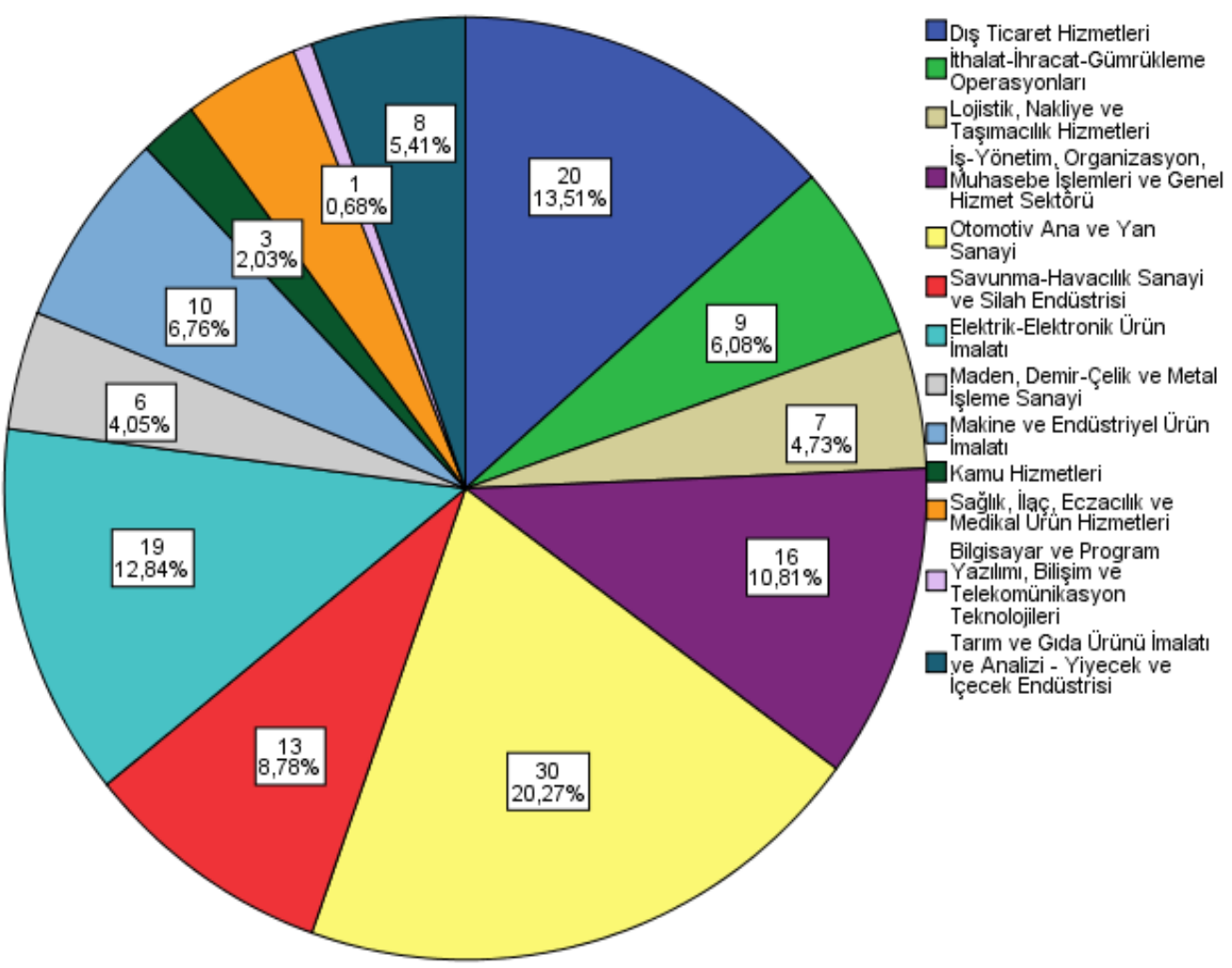

Grafik 2 Uygulama Yapılan İş Yerlerinin Faaliyet Alanları

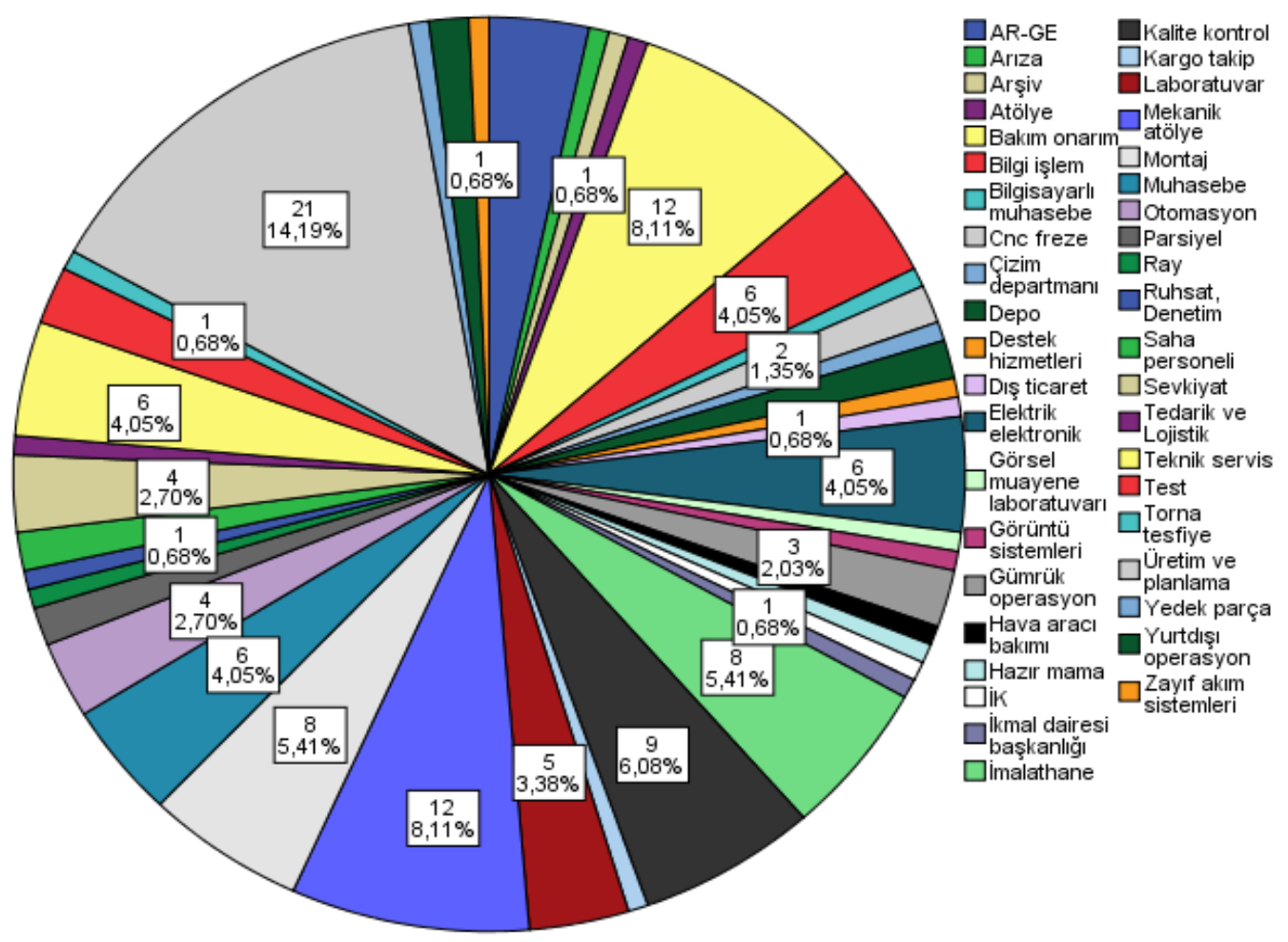

Grafik 3 Uygulama Yapılan Departmanlar 
Öğrencilere sunulan ücret bilgileri Tablo 2'de istihdam bilgileri de Tablo 3'te sunulmuştur.

Tablo 2 Ücret Bilgileri

\begin{tabular}{|c|c|c|c|c|}
\hline $\begin{array}{c}\text { Ücret Alan } \\
\text { Ŏğrenci Sayısı }\end{array}$ & $\begin{array}{c}\text { Ücret Almayan } \\
\text { Öğrenci Sayısı }\end{array}$ & $\begin{array}{c}\text { Minimum Ödenen } \\
\text { Ücret Miktarı }\end{array}$ & $\begin{array}{c}\text { Maksimum Ödenen } \\
\text { Ücret Miktarı }\end{array}$ & $\begin{array}{c}\text { Ücret } \\
\text { Ortalaması }\end{array}$ \\
\hline 70 & 78 & 671 & 2.860 & 1.258 \\
\hline
\end{tabular}

Uygulamaya katılan öğrencilerin \%47,3'üne $(\mathrm{N}=70)$ firmalar tarafindan 671 TL ile $2.860 \mathrm{TL}$ aralığında değişen miktarlarda ücret ödemesi yapılmıştır. Ortalama olarak alınan ücret miktarı ise 1.258 TL'dir. Öğrencilerin \%52,7'sine $(\mathrm{N}=78)$ firmalar tarafından ödeme yapılmamıştır. Ödeme yapmayan firma sayısının fazlalığı, Pandemi koşulları nedeniyle yaşanan ekonomik sıkıntılar kaynaklı olduğu değerlendirilmektedir. Ücret dişında öğrencilerin \%50'sine $(\mathrm{N}=74)$; yemek, yemek kartı, ramazan kolisi, hediye, hediye çeki, alışveriş çeki vb. yardımlar yapılmıştır.

Tablo 3 İstihdam Bilgileri

\begin{tabular}{|c|c|c|}
\hline $\begin{array}{c}\text { Uygulama Sonucu İş Teklifi Alan } \\
\text { ve Teklifi Kabul Eden Öğrenci } \\
\text { Sayısı }\end{array}$ & $\begin{array}{c}\text { Uygulama Sonucu İş Teklifi Alan ve } \\
\text { Teklifi Kabul Etmeyen Öğrenci Sayısı }\end{array}$ & $\begin{array}{c}\text { İș Teklifi Almayan } \\
\text { Öğrenci Sayısı }\end{array}$ \\
\hline 48 & 45 & 55 \\
\hline
\end{tabular}

Uygulamaya katılan öğrencilerin \%62,8'ine $(\mathrm{N}=93)$ firmalar tarafından iş teklifi yapılmıştır. Öğrencilerin \%32,4'ü $(\mathrm{N}=48)$ iş teklifini kabul ederken, \%30,4'ü $(\mathrm{N}=45)$ ise iş teklifini kabul etmemiştir. Öğrencilerin iş tekliflerini kabul etmeme nedenleri Grafik 4'te gösterilmiştir.

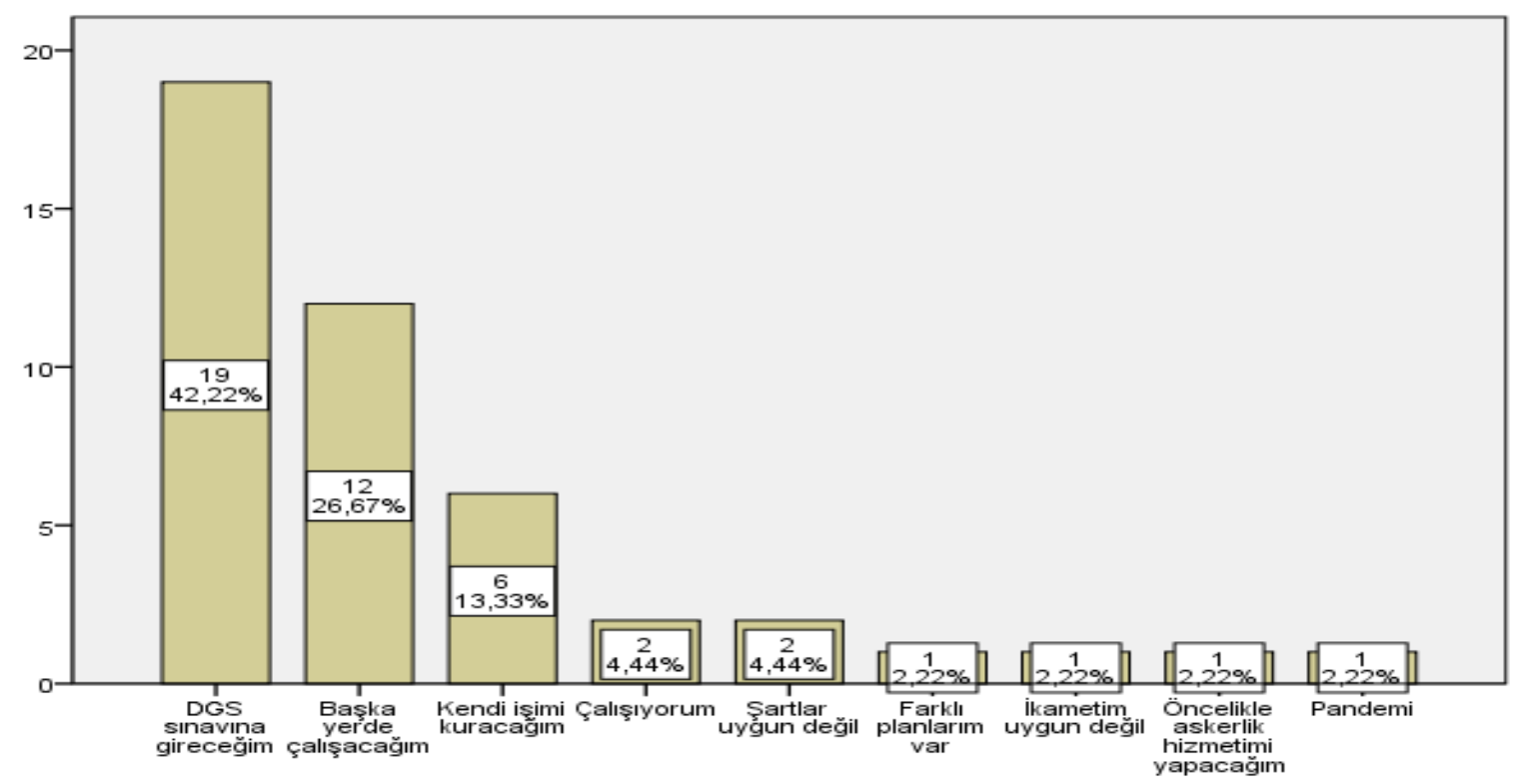

Grafik 4 Öğrencilerin İş Tekliflerini Kabul Etmeme Nedenleri

İş teklifini kabul etmemenin en büyük nedenleri; \%42,2 ile (N=19) DGS sınav1, \%26,7 ile $(\mathrm{N}=12)$ başka yerde çalışma isteği ve \%13,3 ile $(\mathrm{N}=6)$ kendi işini kurma planları olarak gerçekleşmiştir. 
Öğrencilerin \%37,2'sine $(\mathrm{N}=55)$ ise iş teklifi yapılmamıştır. Firmaların iş teklifi yapmama nedenleri arasında en büyük neden personel ihtiyaçlarının olmaması olarak tespit edilmiştir.

3+1 uygulaması bahar yarıyılında 12 hafta süreyle uygulanmıştır. Uygulamaya katılan firmaların \%93'ü $(\mathrm{N}=132) 12$ haftalık sürenin öğrenciyi tanımak ve personel ihtiyacı olması durumunda iş teklifi yapabilmek için yeterli bir süre olarak değerlendirmiştir. 12 haftalık süreyi yeterli bulmayan firmalar, ortalama olarak 20 haftalık bir sürenin daha uygun olacağı yönünde görüş belirtmişlerdir.

Uygulamaya katılan firmaların \%76,8'i (N=109) uygulamanın güz döneminde de yapılması halinde öğrenci kabul edeceklerini beyan etmiştir. Firmaların \%4,9'u (N=7) Pandemi koşullarından dolayı yaşanan belirsizlikler nedeniyle güz döneminde sisteme destek veremeyeceklerini ifade etmişlerdir. Destek veremeyecek diğer firmalar gerekçe olarak; personel ihtiyaçlarının olmaması, proje bazlı çalışmaları ve şirket politikalarını öne sürmüştür.

3+1 modeliyle ilgili öğrenci algılarını ölçebilmek için öğrencilere 19 adet soru yöneltilmiştir. $\mathrm{Bu}$ soruların 2 adedi uygulama öncesi faaliyetler, 8 adedi uygulama esnası firma desteği, 7 adedi modele ilişkin öğrenci algıları ve 2 adedi de Pandemi koşullarına yöneliktir. Öğrencilerin yargılara 5'li Likert Ölçeği (1=Kesinlikle Katılmıyorum, 2=Katılmıyorum, 3=Ne Katıliyorum Ne Katılmiyorum, 4=Kat1liyorum, 5=Kesinlikle Katıliyorum) kullanılarak cevap verilmesi istenmiştir.

Uygulama öncesi faaliyetlere yönelik algılara Tablo 4'te, uygulama esnası firma desteğine yönelik algılara Tablo 5'te, modele ilişkin öğrenci algılarına Tablo 6'da ve Pandemi koşullarına yönelik algılara da Tablo 7'de yer verilmiştir.

Tablo 4 Uygulama Öncesi Faaliyetlere Yönelik Sonuçlar

\begin{tabular}{|l|c|}
\hline \multicolumn{1}{|c|}{ Ifade } & Ortalama \\
\hline Üniversite tanıtım günlerinde 3+1 eğitim modeli hakkında bilgilendirildim & $\mathbf{4 , 2 7}$ \\
\hline Üniversiteye kayıt sırasında 3+1 eğitim modeli hakkında bilgilendirildim & 4,18 \\
\hline Uygulama Öncesi Faaliyetler & $\mathbf{4 , 2 3}$ \\
\hline
\end{tabular}

Uygulama öncesi faaliyetlere yönelik öğrenci algılarının ortalaması 4,23 olarak gerçekleşmiştir. En yüksek ortalama 4,27 ile "Üniversite tanıtım günlerinde $3+1$ eğitim modeli hakkında bilgilendirildim” ifadesinde gözlemlenmiştir. Gerçekleşen ortalamalara dayanarak gerek kayıt öncesi dönemde gerekse kayıt ve sonrası dönemde öğretim elamanları tarafından öğrencilere aktarılan bilgilerle istenen düzeyde model hakkında farkındalık oluşturulduğu ifade edilebilir.

Tablo 5 Uygulama Esnası Firma Desteği Sonuçları

\begin{tabular}{|c|c|}
\hline İfade & Ortalama \\
\hline İş yeri uygulaması süresince iş yerinden gerekli rehberliği, ilgiyi, desteği ve alakayı gördüm & 4,50 \\
\hline İş yeri kendi personelinden beni ayırt etmemiştir & 4,54 \\
\hline $\begin{array}{l}\text { İş yeri kendi personeline sağlamış olduğu servis, yemek vb. imkanları bana da } \\
\text { sağlamıştır }\end{array}$ & 4,58 \\
\hline İş yeri ücret/maaş ödemelerini zamanında hesabıma yatırmıştır & 4,35 \\
\hline $\begin{array}{l}\text { İş yeri uygulaması dersi süresince iş yerinin sağlamış olduğu rehberlik, teknik yetkinlik ve } \\
\text { uygulamalı eğitim hizmeti yeterlidir }\end{array}$ & 4,41 \\
\hline İş yeri uygulaması süresince uygulama yaptığım işletmede birçok olumsuz durum içeren & 4,05 \\
\hline
\end{tabular}


SINAN CAN ALTUNTAS et al. / ISEC2021 Sakarya- Turkey

\begin{tabular}{|l|c|}
\hline sosyal davranışa maruz kaldım (ters kodlanmıştır) & \\
\hline $\begin{array}{l}\text { İş yeri uygulaması yapmış olduğum işletmede organize edilen sosyal aktivitelere ve } \\
\text { faaliyetlere dahil edilmedim (ters kodlanmışır) }\end{array}$ & 4,11 \\
\hline $\begin{array}{l}\text { İş yeri uygulaması yapmış olduğum işletmede diğer personeller, ortak kullanım alanlarında } \\
\text { (yemekhane, ofis, mutfak, servis vb.) objektif olmuşlardır }\end{array}$ & 4,52 \\
\hline Uygulama Esnası Firma Desteği & $\mathbf{4 , 3 9}$ \\
\hline
\end{tabular}

Uygulama esnası firma desteğine yönelik öğrenci algılarının ortalaması 4,39 olarak gerçekleşmiştir. En yüksek ortalama 4,58 ile "İş yeri kendi personeline sağlamış olduğu servis, yemek vb. imkanları bana da sağlamıştır” ifadesinde gözlemlenmiştir. Tespit edilen ortalamalar 1şı̆̆ında uygulama esnasında firmaların öğrencilere gerekli desteği sağladıkları anlaşılmıştır. Uygulamanın 12 hafta süreli zaman kısıtı olmasına rağmen firmaların; öğrencilere sağladıkları destekler, ücretlerin zamanında ödenmesi ve en önemlisi kendi personelinden öğrencileri ayrı görmemelerinin örnek seviyede bir davranış olduğu düşünülmektedir.

$\mathrm{Bu}$ bulgulara dayanarak önümüzdeki dönemde, $3+1$ modeli uygulamasıyla üniversite-sektör iş birliklerinin daha da anlam kazanacağı ve böylece nitelikli işgücünü hazırlamak ve istihdam etmenin daha bilimsel olarak teşekkül edeceği değerlendirilmektedir.

Tablo 6 Modele İlişkin Öğrenci Algıları Sonuçları

\begin{tabular}{|c|c|}
\hline İfade & Ortalama \\
\hline $\begin{array}{l}\text { İş yeri uygulaması dersi; okulda öğretilen teorik bilgilerin pratik uygulamalara } \\
\text { aktarılabilmesi adına yararlı ve faydalı bir eğitim sistemidir }\end{array}$ & 4,48 \\
\hline $\begin{array}{l}\text { İş yeri uygulaması dersi vasıtası ile okulda öğrenilen teorik bilgileri iş hayatında } \\
\text { uygulayabilme şansım olmuştur }\end{array}$ & 4,41 \\
\hline $\begin{array}{l}\text { İş yeri uygulaması dersini tamamlamış olduğum işyerinde mezuniyet sonrasında çalışmak } \\
\text { istemekteyim }\end{array}$ & 3,80 \\
\hline $\begin{array}{l}\text { İş yeri uygulaması dersi yerine okulda teorik dersin devam etmesi görüşündeyim (ters } \\
\text { kodlanmıştır) }\end{array}$ & 3,64 \\
\hline İş yeri uygulaması dersini gereksiz bir faaliyet olarak görmekteyim (ters kodlanmıştır) & 4,23 \\
\hline $\begin{array}{l}\text { İş yeri uygulaması yaptığım işletmeyi iş yeri uygulaması yapacak olan arkadaşlarıma } \\
\text { tavsiye etmeyi düșünürüm }\end{array}$ & 4,32 \\
\hline $\begin{array}{l}\text { İş yeri uygulaması planlı ve düzenli çalışma, ekip ve takım çalışmasına dahil olma gibi } \\
\text { hususlarda etkin rol oynamıştır }\end{array}$ & 4,55 \\
\hline Modele İlişkin Öğrenci Algıları & 4,18 \\
\hline
\end{tabular}

3+1 modeline yönelik öğrenci algılarının ortalaması 4,18 olarak gerçekleşmiştir. En yüksek ortalama 4,55 ile "İ̧s yeri uygulaması planlı ve düzenli çalışma, ekip ve takım çalışmasına dahil olma gibi hususlarda etkin rol oynamıştır" ifadesinde gözlemlenmiştir. Modele ilişkin öğrenci algıları doğrultusunda model uygulamasının öğrenci beklentilerine cevap veren bir sistem olduğu ifade edilebilir. Özellikle öğrencilerin teorik bilgilerini iş hayatında uygulama şansı elde etmiş olmaları ve uygulama yaptığı firmalardan iş teklifi almaları üniversite eğitimi sonrasındaki belirsizliklere 1ş1k tutabilecek derecede önemli bir bulgu olarak değerlendirilmektedir.

Tablo 7 Pandemi Koşullarına Yönelik Sonuçlar

\begin{tabular}{|l|c|}
\hline \multicolumn{1}{|c|}{ İfade } & Ortalama \\
\hline Pandemi dolayısı ile iş yerinde istediğim performansı sergileyebilme imkânım olmamıştır & $\mathbf{2 , 4 8}$ \\
\hline $\begin{array}{l}\text { İş yeri uygulaması yapılan işletmede Pandemi kurallarına (maske, mesafe, temizlik) } \\
\text { uyulmuştur }\end{array}$ & $\mathbf{4 , 5 8}$ \\
\hline
\end{tabular}


Gerçekleşen ortalamalara göre Pandemi koşullarının öğrencilerin performanslarını ortaya koymada problem olmadığını ve iş yerlerinin maske, mesafe ve temizlik gibi gerekli kurallara uyduğunu ortaya çıkarmıştır.

Uygulama yapılan iş yerinde iş yerinden kaynaklı sosyal problem yaşanma durumuna yönelik sorulan açı uçlu soruya öğrencilerin $\% 86,5^{\prime} \mathrm{i} \quad(\mathrm{N}=128)$ herhangi bir problem yaşamadıklarını beyan etmişlerdir. Öğrencilerin \%3,4'ü $(\mathrm{N}=5)$ problem yaşadığını ancak kısa sürede çözüm üretildiğini belirtmiştir.

İş yeri uygulamasıyla ilgili ilave olarak ifade etmek istedikleri hususlara yönelik olarak sorulan açık soruya öğrenciler; tecrübe kazandıkları çok faydalı bir uygulama olduğu, okulda öğrendikleri teorik bilgileri uygulamada kullanabildiklerini, disiplinli ve programlı çalışma esaslarına alıştıkları, iş hayatına hazırlık açısından ciddi katkılar edindiklerini ifade etmişlerdir.

3+1 uygulamasıyla ilgili firma algılarını ölçebilmek için firmalara 10 adet soru yöneltilmiştir. Firmaların yargılara 5'li Likert Ölçeği (1=Kesinlikle Katılmıyorum, 2=Katılmiyorum, 3=Ne Katılıyorum Ne Katılmıyorum, 4=Katılıyorum, 5=Kesinlikle Katıliyorum) kullanılarak cevap verilmesi istenmiştir. Firma algılarına yönelik sonuçlara Tablo 8'de yer verilmiştir.

\section{Tablo 8 Firma Algılarına Yönelik Sonuçlar}

\begin{tabular}{|c|c|}
\hline İfade & Ortalama \\
\hline $\begin{array}{l}\text { İş yeri uygulaması süresince iş yerimize gelen öğrenciler işletmede verimli şekilde ve } \\
\text { işletmeye katkı sağlayarak çalışmışlardır }\end{array}$ & 4,64 \\
\hline $\begin{array}{l}\text { İş yeri uygulaması dersi; okulda öğretilen teorik bilgilerin pratik uygulamalara } \\
\text { aktarılabilmesi adına yararlı ve faydalı bir eğitim sistem modelidir }\end{array}$ & 4,64 \\
\hline $\begin{array}{l}\text { İş yeri uygulaması dersi vasıstası ile iş yerimize yönlendirilen öğrenciler okulda öğrendikleri } \\
\text { teorik bilgileri iş hayatında uygulayabilme şansları olmuştur }\end{array}$ & 4,50 \\
\hline $\begin{array}{l}\text { İş yeri uygulaması dersi yerine okulda teorik derslerin devam etmesi görüşündeyim (ters } \\
\text { kodlanmıştır) }\end{array}$ & 3,45 \\
\hline $\begin{array}{l}\text { İş yeri uygulaması dersini gereksiz ve verimsiz bir faaliyet olarak görmekteyim (ters } \\
\text { kodlanmıştır) }\end{array}$ & 4,46 \\
\hline $\begin{array}{l}\text { İşyeri uygulaması dersi süresince iş yerimizin sağlamış olduğu rehberlik, teknik ve } \\
\text { uygulamalı eğitim hizmetinin yeterli olduğunu düşünüyorum }\end{array}$ & 4,40 \\
\hline $\begin{array}{l}\text { İşy yeri uygulaması dersi süresince üniversitedeki koordinatör öğretim elemanının sağlamış } \\
\text { olduğu rehberlik ve iletişim hizmeti yeterlidir }\end{array}$ & 4,03 \\
\hline $\begin{array}{l}\text { İş yeri uygulamas1 süresince yaşadığımız problemlere üniversitenizin ilgili program } \\
\text { koordinatörü olan öğretim elemanı çözüm üretmiştir }\end{array}$ & 4,01 \\
\hline $\begin{array}{l}\text { İş yeri uygulaması dersi Üniversite-Sanayi ve İş Dünyası ortaklığı adına güzel bir eğitim } \\
\text { sistemidir }\end{array}$ & 4,59 \\
\hline $\begin{array}{l}\text { İş yeri uygulaması dersi kapsamında gelecek dönemlerde de üniversitenize destek ve katkı } \\
\text { vermek isteriz }\end{array}$ & 4,06 \\
\hline Firma Algları & 4,28 \\
\hline
\end{tabular}

3+1 modeline yönelik firma algılarının ortalaması 4,28 olarak gerçekleşmiştir. En yüksek ortalama 4,64 ile "İş yeri uygulaması süresince iş yerimize gelen öğrenciler işletmede verimli şekilde ve işletmeye katkı sağlayarak çalışmışlardır” ile "İş yeri uygulaması dersi; okulda öğretilen teorik bilgilerin pratik uygulamalara aktarılabilmesi adına yararlı ve faydalı bir eğitim sistem modelidir" ifadelerinde gözlemlenmiştir. Aynı zamanda 4,50 ortalama ile gerçekleşen "İş yeri uygulaması dersi vasıtası ile iş yerimize yönlendirilen öğrencilerin okulda öğrendikleri teorik bilgileri iş hayatında uygulayabilme şansları olmuştur" yargısının da çok önemli bir sonuç olduğu düşünülmektedir.

Firma algılarına yönelik ortalamaların oldukça yüksek olarak tespit edilmiş olması nedeniyle 3+1 model uygulamasının sektör tarafından da desteklenen bir uygulama olduğu 
değerlendirilmektedir. Dolayısıyla firmaların gelecek dönemde de uygulamaya destek verecekleri yönünde bir öngörüde bulunulabilir. Firmalara yöneltilen son sorunun gerçekleşen 4,06 ortalamas1 da öne sürülen öngörüye dayanak olarak belirtilebilir. Aynı zamanda, uygulama sırasında öğretim elemanları tarafından sağlanan desteklerin firma bakış açısıyla da yeterli seviyede olduğu teyit edilmiştir.

Firmalara uygulamaya gelen öğrencilerden beklentilerinin sorulduğu açık uçlu soruya; \%23,1'i $(\mathrm{N}=33)$ ahlakl1, düzenli, disiplinli, çalışkan olmaları, \%8,4'ü $(\mathrm{N}=12)$ öğrenmeye açık olmaları, \%6,3' $\ddot{\mathrm{u}}(\mathrm{N}=9)$ sorumluluklarını kabul etmeleri ile işi zamanında istenildiği gibi yapmaları, $\% 5,6$ 's1 ( $\mathrm{N}=8)$ saygılı olmaları ve \%4,2'si $(\mathrm{N}=6)$ kurallara uygun davranmaları olarak ifade edilmiştir. Bu yargılarla birlikte düşük oranlarda öğrencilerin; istekli, azimli, meraklı, sorgulayıcı, araştırmacı, kendine güvenen ve kendine geliştirmeye istekli olmalarına yönelik değerlendirmeler yapılmıştır.

İş yeri uygulaması dersinin Pandemi koşullarında icra edilmesine yönelik düşüncelerin sorulduğu açık uçlu soruya; \%37,1'i $(\mathrm{N}=53)$ maske, mesafe ve temizlik kurallarına uyumda problem olmadığı, \%9,8'i $(\mathrm{N}=14)$ uygulamanın Pandemi koşullarında zor olsa bile öğrencilerin kişisel gelişimleri için gerekli olduğu, \%5,6's1 (N=8) Pandemi döneminde bu tür uygulamaların yanlış olduğu, \%4,9'u (N=7) Pandemi nedeniyle herhangi bir zorluk yaşamadıklarını beyan etmişlerdir.

İş yeri uygulaması için firmaya gelen öğrencilerden kaynaklı işe uzak durma, iş yerinin düzenini bozucu tavırlar sergileme, öğrenmekten kaçınma, uyumsuzluk, performans düşüklüğü vb. sosyal problemlerle ilgili sorulan açık uçlu soruya; firmaların \%80,4'ü (N=115) sorun yaşanmadığını belirtmişlerdir.

İş yeri uygulaması dersi konusunda ilave olarak belirtilmek istenen olumlu/olumsuz düşüncelere yönelik açık uçlu soruya; firmaların \%14,7'si $(\mathrm{N}=21)$ uygulamanın hem firma hem de öğrenci için çok faydalı bir uygulama olduğu, \%8,4'ü $(\mathrm{N}=12)$ teorik bilginin pratiğe aktarılması için mükemmel bir firsat olduğu ile öğrencilerin iş hayatına daha iyi hazırlanabilecekleri, \%5,6'sı (N=8) öğrenciyi yakından tanıma imkanlarının olmasının büyük bir avantaj olduğu, \%3,5'u (N=5) uygulamadan memnun olduklarını, \%2,8'i $(\mathrm{N}=4)$ uygulama süresinin arttırılabileceğini ifade etmişlerdir.

\section{SONUÇ}

Üniversite-sektör iş birliklerinin önemi her geçen gün daha da artmaktadır. Özellikle sektörün ihtiyaç duyacağı nitelikte öğrenci yetiştirebilme kaygısı yüksek öğretim kurumlarını çok daha fazla çaba sarf etmeye yöneltmektedir.

$3+1$ benzeri uygulamalarla sektör beklentilerinin ne oranda karşılandığı tespit edilebilmektedir. Yapılan tespitlerin; ihtiyaç duyulan programların açılması, programlarda ders içeriklerinin belirlenmesi/güncellenmesi, teori/laboratuvar uygulamalarının senkronizasyonu gibi akademik faaliyetlere yön veren çok değerli bulgular olduğu düşünülmektedir.

3+1 uygulamasıyla öğrencilerin üniversite eğitimini bitirmeden teorik bilgilerini pratikte uygulama imkanına ulaşmış olmaları gelecek iş yaşantıları açısından önemli bir deneyim olarak değerlendirilmektedir. Aynı zamanda üniversite eğitimi sonuna kadar çalışma deneyimi olmayan öğrencilerin bu tür uygulamalarla; iş yeri kuralları, amir-ast ilişkileri, ekip çalışması, örgüt kültürü gibi konularda deneyim sahibi olacakları ifade edilebilir. Bu sayede iş yaşantısına adaptasyonlarının daha kolay ve sağlıklı olacağı öngörülebilir.

Tespit edilen sonuçlar gerek öğrenci gerekse firma açısından 3+1 uygulamasının çok faydalı bir faaliyet olduğunu ortaya çıkarmıştır. Firmaların gelecek dönemlerde de uygulamaya destek 
SINAN CAN ALTUNTAS et al. / ISEC2021 Sakarya- Turkey

sağlayacakları yönündeki bulgular kurgulanan sistemin gelecekte de rahatlıkla uygulanabileceğine yönelik bir sonuç olarak değerlendirilmektedir.

Y1llara sâri elde edilecek bulgularla $3+1$ sisteminin mükemmelleştirilmesine yönelik tespitler yapılabileceği ifade edilebilir. 